\title{
DIDACTIC SKILLS IN THE FIELD OF DEVELOPING CREATIVITY AND INNOVATIVENESS OF A STUDENT
}

\begin{tabular}{|c|c|}
\hline \multicolumn{2}{|c|}{$\begin{array}{l}\text { Dr. Anna Kožuh, University of Primorska, Slovenia; AFM Krakow, Poland } \\
\text { E-mail: ania@kozuh.net }\end{array}$} \\
\hline ART I C LE I N F O & $\begin{array}{l}\text { A B S T R A C T } \\
\text { The authoress of this article highlights the areas of mutual connections }\end{array}$ \\
\hline Review Article & and dependencies between theory and practice of students' creative \\
\hline Received: January, 28.2020. & development, making at the same time an attempt to show creativity against \\
\hline Revised: February, 05.2020. & the background of didactic competence of a teacher. She describes the \\
\hline Accepted: February, 10.2020. & discussed creativity in the teachers' attitude primarily as an incessant search \\
\hline doi: 10.5937/IJCRSEE2001069K & $\begin{array}{l}\text { for better didactic solutions, discovering new learning opportunities and } \\
\text { challenging the hitherto accepted assumptions of working with students. She }\end{array}$ \\
\hline UDK & points out that the leading trait of the teacher's creativity is also the ability to \\
\hline 37.091 .3 & look for different ways of solving the same problem. In this article creative \\
\hline Kеуw & $\begin{array}{l}\text { of creating more effective methods for a teacher to work with his or her } \\
\text { students and facilitate their development and growth on many creative levels. }\end{array}$ \\
\hline
\end{tabular}

creativity and innovativeness,

creative attitude,

teacher's didactic workshop,

didactic initiatives and challenges,

creative teachers.

(c) 2020 IJCRSEE. All rights reserved.

\section{INTRODUCTION}

Attempts to put innovative and creative tasks before students appeared many times in the long history of didactics. However, recent decades have been exceptionally strong and dynamic in this type of activity. More and more often teachers create and implement their didactic projects not only on the basis of knowledge gained during their studies or teacher refresher courses, but under the influence of various creative inspirations from the world of movies, books or art. Teachers for whom the challenges posed by creative education are the key issues should make every effort to make sure that tasks requiring non-standard student activities become everyday life in their schools. All educational projects, in accordance with modern education standards, should, as a rule, pose problems to the student that require analytical research and unconventional solutions.

Corresponding Author

Dr. Anna Kožuh, University of Primorska, Slovenia; AFM Krakow, Poland

E-mail: ania@kozuh.net

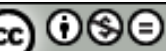

This work is licensed under a Creative Commons Attribution - NonCommercial - NoDerivs 4.0. The article is published with Open Access at www.ijcrsee.com
The creative attitude of the teacher is characterised above all by the ability to compare issues that are different from one another, the aptitude to perceive what is imperceptible for others and to approach a problem from different points of view. It is also the ability to look for many different ways to solve the same problem. According to this definition, creativity depends, among other things, on challenging the assumptions, discovering new opportunities and searching for better solutions. Therefore, creative teachers frequently use their imagination and are future oriented. They take risks more often than their less creative colleagues and are able to adapt to changes taking place in their environment. Creative teachers also quickly perceive relations among elements, which at first glance seem to be unrelated. There are also important emotional components present in the attitude of a creative teacher, such as empathy, interpersonal communication, active listening skills, openness to the unknown, courage in taking decisions and a sense of humour. Teacher's ingenuity, his or her imagination and ability to go beyond the accepted schemes and the courage to disprove and break the stereotypes of thinking. The teacher's educational creativity also includes non-stereotypical actions and following a route which has not been discovered earlier. It is the teacher and the type of class activities 
proposed by him that influence the student's comprehensive development and allow them to fully accomplish the objectives of modern education. After all, one must not forget that education, filled with unusual initiatives and organised as a creative didactic process guarantees students, as graduates of individual types of school, a successful life and a sense of accomplishment.

\section{THEORETICAL CONCEPTS AND UNDERTAKEN CREATIVE ACTIVITIES}

Examples of non-standard and creative activities involving participation of students are popularized not only in various media but, above all, in educational theory and practice. Many pedagogical research studies discuss the problem of innovative activities in which schemes and stereotypes are abandoned. This problem has been discussed many times in the literature on instruction and education over the last decades. It concerned both creative pupils and creative teachers, accepting different terms interchangeably (Kožuh 2017, Łukasiewicz 2007, Nęcka 1998, Olearczyk 2010, Popek 2001, Renzulli, Reis and Thompson 2009, Smak 2014). Almost all the mentioned authors agree that working with a student, improving his creative competency, is a responsible and very difficult action. One of the reasons for these difficulties is the fact that these competencies often go beyond the knowledge and skills acquired in the standard teacher training process. Perhaps this is why teachers, who are graduates of philosophy, sociology, medicine, art and other fields of study are doing well with untypical tasks addressed to students (e.g. the educational activity of people like Edward de Bono, Tony Buzan, Maria Montessori).

The idea of education, the aim of which is to develop students' ability to solve problems, make decisions, cooperate, as well as communicate and express themselves in many ways, assumes many other school concepts, including the Reggio pedagogy, based on the philosophy of Loris Malaguzzi. This is a school that offers inspiration for learning, not the classical teaching, based on memorizing messages without understanding them and the ability to put them into practice. This concept, which is an innovative approach to early education, proposes simple but interesting and provocative didactic materials, as a source of motivation and patience in searching for unusual answers by the student (Edwards and Gandini 2011). Apart from pedagogues, the teachers in such a school are artists representing various fields of art, including graduates of photography, computer graphics, interior architects and designers, painters, musicians and sculptors.

\section{DIRECTIONS FOR MODIFICATION OF TEACHERS' DIDACTIC PREPARATION TO UNDERTAKE CREATIVE CHALLENGES}

The increasing need for constant invention of creative tasks should, therefore, be an opportunity for reflection for theoreticians of pedagogy and for authors of academic syllabuses training future teachers. Perhaps it is worthwhile to further modify the system of education at university by setting students - future teachers - more and more tasks that require non-stereotypical solutions. Perhaps it is also necessary to intensify classes at the academic level in such a way that projects addressed to students of teacher training courses encourage unconventional approach in searching for creative solutions and answers.

The literature of the subject strongly emphasizes that the most developing are workshops that enable discovering the secrets of the world in completely new ways (Adamek and Bałachowicz 2014). From this perspective, it is worth looking at the need for a complete professional preparation of the teacher and the process of his or her continuous development. This is how the popular slogan "creative development of the teacher" was conceived, of which Żechowska writes: "it can be understood as a theoretical vision, opportunity, chance and as a real process among real teachers" (Żechowska 1996, p. 54).

\section{EXPECTED DIDACTIC SKILLS IN TERMS OF CREATIVITY AND NEW CHALLENGES FOR THE TEACHER}

These considerations concern the position of creativity in the perspective of didactic competency of the contemporary 
teacher, since the assumption of a modern educational process is the frequent use of seeking didactic methods and implementation of heuristic strategies. These methods are very popular in didactics as they initiate students' divergent thinking, enable them to discern and solve problems and analyse them from different points of view. Teacher's creative attitude is necessary and indispensable for proper planning and implementation of classes based on such methods. In the didactic space, the teacher plays the role of "the locomotive of pedagogical progress", without which setting off railway carriages on the long, independent journey to earlier unknown stations is impossible. This teacher is undoubtedly a moderator of the creative method of students' work and their guide to effective, creative problem-solving strategies. Constant reflection on one's own actions and evaluation of students' activeness as well as the ability to predict the consequences of certain definite behaviours that are undoubtedly the skills which foster the development of teachers' creativity.

Currently, the problem of the place of creativity among the didactic competency of the teacher has acquired new significance, and the creative attitude of the teacher has become an essential element of each educational initiative, since cultural and social transformations force a more innovative course of the process of teaching, as well as a faster and more complete development of creative abilities of both, the teacher and the student. This is a new challenge for school and teachers working there. The need to equip teachers with the ability to take up creative actions in the process of education and to expect creative attitudes from their students results from the conviction that learning to be creative cannot be accomplished otherwise than by participating in creative activities. In order for a student to be able to solve problems creatively, the theory and the knowledge of the principles of creative activity are not enough. From this perspective, one should also consider the necessity to modify the content of the concepts of teacher training and the process of its continuous development.

\section{CONCEPTUAL ASSUMPTIONS FOR THE DEVELOPMENT OF TEACHERS' AND STUDENTS' CREATIVITY IN POLAND}

The system of education in Poland and in other European countries has undergone numerous transformations in recent years. All this happened, inter alia, due to adoption of common directives for the "Old Continent" concerning the modification of education at all levels of education. Many of those documents caused reconstruction of educational syllabuses or their modernisation. These changes also apply to reorganisation and improvement of syllabuses and training of the teaching staff. Among the postulated competencies and characteristics of the teachers, their teaching skills, particularly their competency in the field of recognising the surrounding reality, planning their own activities and designing activities of the students, are clearly emphasized (Klus-Stańska 2010). All the skills mentioned above fit into the definition of creativity as an element of the teacher's didactic workshop. In the literature concerning teaching and education over the last few decades, the problem of creativity in didactic initiatives has been discussed repeatedly. Almost every time it adopted different concepts, various definitional attempts and different perspectives. Among them, one can find such concepts as: lessons of creative thinking, didactics of creativity, education with imagination, school of creativity, education for creativity, future oriented education, upbringing, education for freedom, as well as education for and through art. Among the authors, who addressed this issue, one should mention such names as: Dobrołowicz, Giza, Limont, Moroz, Nęcka, Renzulli, Szmidt and Żechowska (Dobrołowicz 1995, Giza 2006, Limont 2005, Moroz 1996, Nęcka 2001, Renzulli 1976, Szmidt 2013 and Żechowska 1996).

However, there is a concern that the process of education which offers the students mostly expository methods may turn out to be too complicated and insufficient for them. In the case of excess of expository methods, the contents of learning may be difficult to understand for the students, and hence difficult to memorize and to make use of in solving typical problem situations. Popek associates the creative attitude with such traits as: independent observation, creative 
imagination, divergent thinking, intellectual flexibility, cognitive activity, high intellectual efficiency and construction skills (Popek 2001). Whereas in the characterological sphere, Popek describes the creative attitude as non-conformism, which he defines as independence, activeness, expression, tolerance and high self-esteem. It should also be emphasized that according to the author of this concept, a true creator appreciates not only his own ideas, but ideas of other people as well. According to the author of the concept, a desirable skill of a creative person is also encouraging others to generate creative, full of original solutions, ideas. All the ideas proposed by Popek are at the same time very recognisable features of a creative teacher.

Among the key factors conditioning the creative process and formation of the creative personality of the student, there are often the sense of freedom, diligence as well as tasks and issues posing challenges mentioned. This list was supplemented by Dobrołowicz with the element of cooperation and mutual understanding of intentions. The author writes, among other things, that "the times of individual explorers and inventors are over (...) success is the result of cooperation, which can also be triggered by the so called synergetic effect" (Dobrołowicz 1995, p. 155).

It should be clearly emphasized, however, that the theories of a teacher's creativity point out the fact that the level of creative performance of the profession can and must be continually improved. There is also a very important recommendation included in those assumptions, which emphasizes that not everything in this respect is the responsibility of the teacher, and the teacher is not the only person to be blamed for the style of his work. In her successive studies quoted hereunder, Żechowska arrives at the same conclusions, when she writes: "the teacher's creativity originates not only from the "internal" conditions (of the teacher's personality), but also from "external" conditions, i.e. from "external" situational pressures which are generated in the course of implementation of new and more complicated tasks set before the teacher (Żechowska 1996, p.59). In the opinion of Żechowska, a significant part in creative development of teachers is played by two variants of their potential abilities. The first one is the interpretative competency, articulating their ability to see the world and perceive other people and themselves in unceasing transformations. It is also the awareness of the dynamics of the world, which provokes asking questions and looking for new non-schematic and creative answers. The other variation of creative abilities necessary in the didactic work of a teacher are the selfcreation competencies, defined as the abilities of a teacher to deliberate and originating from his or her own need for self-development, in compliance with their individual system of values. These competencies, in the context of the discussed concept stimulate innovative activities, which are a manifestation of the creative attitude of the teacher (Żechowska 1996). The concept of Żechowska is quite close to the model of Kwaśnica, who divides professional development of a teacher in the area of creativity into a number of phases (Kwaśnica 2007). In his reflections, the author particularly emphasizes the phase of creative transgression of the professional role, which is manifested in the teacher's critical attitude to the professional convention and in the teacher's quest to liberate himself or herself from this convention. This process is closely connected with the teacher's awareness of his or her professional commitment to a student, and to themselves as well. It is, therefore, the maturation of the teacher in the context of the sense of their own autonomy in their profession. Teachers who continually develop their professional workshop, finally reach such a level of criticism that it allows them to understand themselves and find their own methods to solve didactic problems.

Among the theories of creativity in Poland, attention should certainly be drawn to the concept of the creative process by Nęcka (Nęcka 2001). The author perceives the creative process as an interaction between the target and the test structures. The author understands the target as something that an individual desires in order to achieve something new and valuable, and defines the test structures as something of transitory nature that an individual creates in response to requirements of the target. Nęcka considers the creative process as a phenomenon subject to the principle of self-organization at the levels of strategic control selection and stage control, as well as at the level of performance. This distinction serves to "isolate the essential heuristic strategies involved in the creative process and intellectual operations that execute commands coming from a higher level of self-organisation" (Nęcka 2001). Among the heuristic strategies, which are to serve as decision-making and control functions in the creative process, Nęcka distinguishes, among other things, the strategy of vigilance, i.e. 
sensitization to the reception of only certain classes of stimuli. In addition to the heuristic strategies mentioned above, intellectual operations, which directly affect creative interaction, are very important elements of the Nęcka's model. As for creative cognitive operations, the author includes the following elements: deductive reasoning, inductive reasoning, metaphorical thinking, making associations, abstracting and transforming. These operations occur also in other forms of cognitive activity, however, in creativity we have to deal with their special course, so that the resulting work exhibits unusual and unparalleled properties. At the same time, these operations are typical lesson strategies, regardless of the fact whether the seeking or expository methods become dominant. Regardless of the choice of the basic didactic methods in classes with students, deductive reasoning, inductive reasoning, metaphorical thinking as well as making associations are the leading components of the educational workshop of each teacher. Another important element of the Nęcka's model is the supply of creative processes, that is the inflow of information and power supply, i.e. the appropriate motivation (Nęcka, Orzechowski, Słabosz and Szymura 2005). An equally important element of the discussed model is critical thinking, which makes it possible to make decisions and seek answers to the question whether a given idea meets the requirements of the objective, whether it is advisable to continue the interaction and refrain from breaking off the creative process. The last element of the discussed concept is a typical component of almost any problem method applied in the process of teaching at all its levels.

Deliberations on the problem of creativity in education were taken up also by Moroz (Moroz 1996). Analysing adaptive situation of a young teacher, the author believes that each new lesson, every new topic and objective of a lesson compels the teacher to modify his or her behaviours and to change the previously chosen lines of action. According to Moroz, in this way the teacher becomes the subject of the didactic process. In the author's opinion, when teachers are functioning at the creative level, they cannot be expected to conduct their lessons according to the pattern that they have learnt. Moroz believes that this stage applies to the teachers with pedagogical experience and effective creative work in the form of numerous modifications of educational procedures.
The problem of the area of teaching activities, aimed at developing creative attitudes of students was also taken up by Teśluk (Teśluk 1999). The authoress draws attention to these aspirations, writing "opinions on the role of the teacher have changed considerably throughout history. Teachers' tasks were differently viewed by the Herbartians than the advocates of the new mainstream education. Despite such rich experience from the past, contemporary school is still going through a crisis (...). Such a vision is opposed by new trends aimed at building a "different school", open to the surrounding world, creative and progressive, which stimulates students to independent initiative, accustoms students to self-education, shapes their interests. The proposal to create such a school sets a completely new role for the teacher in the process of education. Currently, teachers do not fulfil their social role, but they are actively involved in co-creating it" (Teśluk 1999, p. 96). Teśluk also attempted to present a synthetic image of a creative teacher, in which she sums up all his or her significant competencies, skills and predispositions, when she writes: “(...) a creative teacher is an ingenious teacher, open to other people's ideas, constantly increasing his or her substantive knowledge and upgrading his or her qualifications. They are constantly faced by new didactic and educational situations. Their activities cannot be schematic, formalized, but it also requires constant searching, verification and elaboration of new solutions. A creative teacher fully embraces himself or herself as a person. He accepts himself and recognizes himself in the categories of change and constant movement. A creative teacher ceaselessly searches, studies, experiments and tests different methods of solving problems. He is a person dedicated to what he or she does, responsible, original, persistent in pursuing his or her objectives, characterised by flexible thinking" (Teśluk 1999, p. 97). Teśluk's concept is a perfect résumé of the part of the article, which deals with the problem of the place of creativity among the didactic competencies of the teacher. The author aptly points out the fundamental didactic posed before the teacher, who is open to other people's ideas, constantly seeks, studies, experiments and tests different ways of solving problems. These creative skills of the teacher are the starting point of effective teaching initiatives.

An important area in the discussion on creativity is the problem of impediments in the creative process. An attempt to analyse 
this issue can be found among other things in the Nęcka's model discussed above. Among barriers to the development of creativity, the author mentions processes which he considers to be antagonistic to creativity. They include, among others, mechanisms preventing the initiation of the creative process, among which he emphasizes anti-creative beliefs and competition of motives. Further impediments indicated by Nęcka are the mechanisms causing premature termination of interactions, among which the authors mentions impatience for results. Nęcka emphasizes also mechanisms disrupting the free course of the creative interaction, such as competition, pressure and conformism as well as mechanisms depriving the creative interaction of useful directions of development, such as excessive knowledge and mental inertia. In order to counteract the abovementioned impediments, Nęcka and other authors of studies on didactic activities with students (Klus - Stańska 2010, Kožuh 2016, Tokarz 2005 and Urbańska 2014) suggest teachers to dispense with competition and rivalry and replace them with cooperation and interaction of students during their lessons. The leading element of a teacher's meeting with students should be the strategy of creative education, based on sessions training creativity and application of different activating methods (Nęcka 2001, Śliwerski 2007 and Szmidt 2013).

A review of literature reveals that their working environment sometimes proves to be the barrier to the development of the creativity of the teacher and his students. In the teaching and class community, there are situations in which, due to his or her "different" approach to learning or work, a creative teacher or a creative student is not always well-liked and appreciated by other members of the teaching staff or classmates in a school environment (Kožuh 2016). Another impediment in the development and support of students is the ability to prepare the teaching staff at universities.

The teachers' inability to reflect on their own work is sometimes indicated as one of the barriers restricting the creative teaching process. After all a teacher should spare no efforts to make the classes he or she prepares not only a transmission of thorough knowledge, but they should also enable students to understand and implement the acquired knowledge in practical activities. It is also the call for organizing classes for students in such a way as to make them a source of inspiration for independent and creative reflections. Every day, a teacher should allow his or her student "to see what human nature is hiding, what is its spiritual wealth, the potential which makes man an individual consciously realizing themselves" (Śliwerski, 2007, p. 24). In order to make this postulate come true, teachers should realise the need for creativity in their teaching strategies, because patterns of behaviours or learned methods of reacting have become useless in new conditions and different educational situations. Efforts are being made in education " in which there is a place for both freedom and certain discipline, which invariably accompanies every human action" (Pachociński 1998, p. 44). Placing students in a situation of creation may be an event changing their previous beliefs, attitudes and values. A task formulated in this way causes also the necessity to accompany the students on their way through their development during each lesson.

In treatises on creative initiatives of a teacher in the process of education, the necessity of knowledge of the levels of creativity is strongly emphasized. It allows better identification and understanding of creative activity of the teacher, as well as of his or her students. Among the concepts concerning this area, Nęcka's reflections on creativity in the aspect of the stages of life deserve attention (Nęcka 2001). The author suggests distinguishing four levels of creativity indicating the level of liquid creativity, the level of crystallized creativity, the level of mature creativity and the level of outstanding creativity. For the author, the fluid creativity is a kind of potential as well as the necessity to create other types of creativity. From the point of view of this concept, the cognitive components of the liquid creativity are creative ways of functioning of the cognitive processes, and among them mainly cognitive curiosity and the need for something new. So even this level opens up great opportunities for teachers, because a well organized didactic process is full of initiatives, which students should find interesting, surprising and motivating to undertake research activity in this area. In turn, crystallized creativity involves capitalizing on their potential ability in the pursuit of a selected creative objective, e.g. creative solution of a problem. The cognitive elements at this level of creativity are above all the ability to see problems and the ability to think critically. An opportunity for the development of this level of the student's creativity can be a variety of didactic situations, which make the students face the necessity to solve the 
problem by seeking creative solutions hitherto unknown. Such opportunities for the teacher are offered by the seeking methods and the strategy of creative solving them. At this level, making use of such methods as brainstorming, T. Buzan's mind map or the Six Thinking Hats method by De Bono (De Bono 2015, Buzan 2014) may prove very helpful in the teacher's didactic workshop. The third level identified by Necka is the mature creativity, which consists in taking up important objectives or problems, which from the social point of view are creative and innovative (Nęcka 2001). Working with students within the area of this level may require taking up complex individual or group projects. It should be emphasized that a project as a didactic method is one of the most difficult and demanding initiatives. A project is not only a long-term method of training spread-out over time but, first of all, it is an activity which demands from students very independent design and evaluation of their own work (Kožuh 2017). The final level listed by the author of the concept of creativity levels is the level of outstanding creativity. It should be understood as mature creativity, leading to the creation of works and inventions, which fundamentally change domains of knowledge. From the didactic point of view, this level is a teachers chance to work primarily with particularly gifted students. This also means sustained vertical and horizontal expansion of student's knowledge and giving him or her assignments which require operating skills of the highest creative potential. Such approach to the development of possibilities to seek creative solutions is a very important recommendation for every teacher. The presented typology results, inter alia, in the fact that each level of creativity has its time and place in the process of acquiring skills and knowledge. Therefore, the knowledge of this concept is essential for every teacher planning creative didactic activities. With this knowledge, a teacher has a chance to better understand and diagnose his or her students and then, on the basis of the analysis of their skills, to organize the didactic process more effectively. The foundation of this strategy and its major objective is to stimulate creative thinking of students.

Profound analysis of the issue of creativity as one of the most important didactic challenges for a modern teacher has become a necessity. According to Melosik and Szkudlarek, we live in a "permanent future shock" (Melosik and Szkudlarek 2009, p. 55). Following the pace and understanding of the changes taking place in the world is by no means easy to adults, the more difficult it may prove for a primary school pupil or a high school student. This is why pupils and students often feel lost during school classes and helpless in the face of everyday problems. This uncertainty and confusion of a student sometimes trigger off emotions which head towards aggression in all its possible forms. Such a situation becomes extremely difficult for the teacher then. His or her work, creativity and innovation often become a way out and a step in the right direction

\section{EXAMPLES OF EDUCATIONAL INITIATIVES DEVELOPING STUDENTS' CREATIVITY}

The modern school is still too often closed in patterns. Too much space in it is devoted to teaching and learning substantive contents at the expense of learning to think. Such a school gives its students too few opportunities to develop their creativity, despite the fact that such a potential is certainly dormant in them. In order to wake them, a creative teacher is needed, who will first of all see and appreciate their creative abilities. A teacher is sought, who is able to find a way to develop the potential found and opportunities dormant in the students. Schools should more often and more than evaluate students, arouse their passion for learning and stimulate avocation for acquiring new knowledge. Creating an atmosphere for the development of creativity in school means leaving the student freedom and autonomy in action, as well as consent to his or her mistakes, experiments and risk taking. The creative teacher also inspires students in such a way that they can create situations not fully predetermined or defined in the educational process. In the above-mentioned activities, it is extremely important for the teacher to apply a formative assessment, when referring to the student's work and his or her success, also develops their motivation. The involved student is more willing to take independent action and memorizes the acquired skills and messages with understanding. The most important factors conditioning the creative process and shaping the creative personality of a student often involve a sense of freedom, diligence and problems that are non-standard tasks. An example of this type of challenge for students can be the homework that the students 
of one Italian high school in Fermo received for their holidays in 2015. In Italy, due to the climate of this part of Europe, students enjoy a three-month holiday break. During the holidays (so that they do not forget about the school) they are given homework from many subjects in the form of various essays, a rich reading list, the task to prepare various projects and solve an extensive list of math problems. Some school publications even prepare special editions of summer exercises. Among the holiday recommendations in the teacher's list, there were 15 points for the students. Each of the points, though they sounded simple, was not easy at all. The most difficult, as Bloom argued in the taxonomy of cognitive aims developed in the previous century similarly to other didactic process theorists (Półturzycki 2013) are the tasks belonging to the category requiring the ability to solve unusual tasks, their creative analysis, evaluation, suggesting, predicting and assessment. These were the holiday tasks Cesare Cata set up for his students. This graduate of philosophy at an Italian university and of doctoral studies in the US is convinced that nowadays educational environments need a more innovative school model. In his opinion, school should encourage students more to love learning than to assess them. Moreover, school should stimulate the passion for acquiring knowledge.

Students in a high school specializing in humanities learning Italian, taught by Cata, carry out various and unique initiatives. One of them was their homework for holidays, formulated in a list containing 15 points.

The first task required the student to take a walk along the seashore in complete loneliness a few times in the morning; to look how the sun reflects in the water and thinking about the most beloved things in the world, to feel happy. The second one was to try to use the new expressions the student had learnt that year; the more he or she could say meant the more he or she could think, and the more free he or she was. The third assignment was to read, as it was the best form of rebellion the student could have - by reading he or she would feel like swallows in flight. The fourth one asked to avoid all things, situations and people that cause negative feelings or emptiness. The fifth one advised the student not to worry if he or she felt sad or scared, as summer, like all beautiful things, might cause confusion in people's souls. At the same time it assigned a task to try to keep a diary to describe the student's state of mind, and in September - if you he or she felt like doing it - it could be read as the next point. The sixth exercise was to watch at least one sunrise in solitude. The seventh one asked not to be ashamed to dance. The eighth task was not swear. The ninth point of homework was to be kind. The tenth one asked the student to watch good movies with moving dialogues. The eleventh task was to review the notes from the student's Italian lessons. The twelfth assignment was to practice a lot of sports. The thirteenth one advised the student if he or she met a person who hurt them to talk about it frankly. The fourteenth point asked the student to be as cheerful as the sun and as unrestrained as the sea. And the last, fifteenth one, told the students to behave themselves. The homework constructed in such a way certainly contains not only the theoretical assumptions of creative work with the students in the educational process that I have described above, but also refers to specific practical activities in its form. They are tasks of innovative, unconventional, nonschematic nature and they require students to create an independent project during their implementation.

Examples of didactic tasks developing creativity of the students can be found in almost every school on every continent. They differ only in the quality and substantive content, the frequency of application and the method of didactic implementation together with the process of evaluation and reflection of the teachers. Theoretical assumptions and the practice of creative development of students find application in problem-related tasks, which are no longer a rarity in school. A task from the area of literature, for example, can be as follows: imagine that you are Umberto Eco (Plato, Pablo Picasso or William Shakespeare) and you intend to become the Minister of Culture and Art (or the Director of the Institute of Literature and Art) - write a cover letter in which you will present your past achievements and attempt to define an action plan for this position. Another example of a creative task in the field of language and art: arrange an interview with Paul Gauguin, containing questions and answers, e.g. What or whom do you most often paint? What do you discuss with Vincent van Gogh about? Are you closer to Fauvism or to Symbolism? What role does your fascination with Impressionism play in your work? 


\section{CREATIVITY AS THE FOUNDATION OF ALL DIDACTIC ACTIVITIES OF THE TEACHER}

In didactic situations, theoretical assumptions are usually well planned and skilfully implemented. Teachers are familiar with the theory of teaching and the wealth of methods developing creative thinking. Such methods certainly include unfinished sentences and unfinished stories, brainstorming, mind map and others. A teacher of Polish elementary school knew this well, when she asked her students to complete a story beginning with a fragment of a sentence that read: "When Magda opened her eyes ...". A ten-year-old student of Polish primary school managed this task perfectly, preparing the following story: When Magda opened her eyes, she saw a magpie that tapped its beak on the parapet of an open window. It was spring, so birds came. Madzia was surprised because a number ten had also arrived. Magda called her mother, but instead of her mother, a cat came. Magda said: Mom? The cat: Yes, my daughter. Then Magda called her Dad. Instead of her dad, a panda came. Madzia said; Dad, is that you? The panda said: I am. Then Magda went downstairs to the hamster. Instead of the hamster, she saw Garfield in front of the TV. Suddenly the doorbell rang. She opened the door and saw the Illuminati who gave her a parcel. Madzia said good-bye to Illuminati. Illuminati walked away and was run over by the cat-roller. In the meantime, Magda opened the package and saw a portal, so she entered it and found herself in the inverse world. After an hour she reached her home. She went to the kitchen to have something to eat and drink, and saw a beaver who fried pancakes on a frying pan. She took the bread from the drawer. She was surprised because the bread had legs and hands and it walked into Magda's mouth. Magda enjoyed eating it. She poured herself some water that splashed all over her. Madzia woke up and it turned out that it was just a dream."

The teacher did much worse with the task than her student. In her assessment, she not only failed to recognize the creative potential of her student, but also committed a number of other didactic mistakes in evaluation of his work. Her assessment was expressed by a red line crossing out the entire text written by the student and a commentary written underneath: "Please, correct the story and write something sensible. You are supposed to write maximum 8 sentences".

Such an assessment done by a teacher is difficult to comment on. Not only was she unable to see the unlimited layers of imagination and fantasy, which are a measure of creativity, but she also tried to limit and enclose the student's creative story in the diagram of eight sentences. Wrong assessment of a student violates a number of didactic and ethical principles in the process of education. The above task also shows, on the one hand, good theoretical assumptions both in the field of education and in the area of initiating creative development of the students, and on the other hand, it points out the poor practice in recognizing their creative development. It is just one of many examples of the gap between theory and practice in teachers' work in all areas of education and at all levels of education.

\section{CONCLUSIONS}

Education described as creative and innovative has been one of the most desirable features of the school in recent years. In the dynamically changing world, the challenges addressed to students, which consist in creating reality in a non-stereotypical way, are more clearly discerned. Educational activities conducted in this field in various parts of the world are more and more frequently analyzed. Many creative tasks and innovative concepts are also offered by the Polish and European school.

Students need teachers who will provoke them to think creatively and to search for themselves. Modern school needs teachers, who not only transmit knowledge, but let their students experience it as well. The wanted teachers are those, who can be guides in studying, discovering and analysing reality by their students.

Teachers wanting to perform their functions conscientiously are obliged to constantly seek new ways of conduct and modifying their behaviours. Each new lesson and each new topic discussed with their students and pupils of any age compels them to change the previously assumed lines of acting. Creativity thus becomes a constant element of didactic work of any teacher, because the unknown and risk are ceaselessly connected with the educational reality in which it operates. For modern teachers it means a change in their role. Nowadays, 
teachers passing judgements and all-knowing experts are not necessary any more, but there is a great demand for teachers who facilitate learning and help in constructing knowledge. This gives rise to the need for creators of safe scientific environment that promotes creative activity of students.

The presented didactic portrait of a creative teacher is evidence of extremely high demands posed to those who would like to meet the desired style of work with a student. So the question arises about who could be able to meet such exorbitant expectations. This raises the question of who would be able to meet such high expectations. Should we revert to the belief that the teaching profession can only be performed by people with the so-called "vocation"? Or maybe there is a chance to develop and improve competencies in the process of training students and adepts of the teaching profession, which would allow teachers to pursue their profession in a creative way? Creative attitudes among students usually develop due to a positive didactic environment and a positive image of themselves. New, creative ideas come up when students seek and see the necessity of constant changes. This is possible only when such activities are accompanied by a full commitment from the creative teacher, as well as the inquisitiveness and inner motivation of the active students.

\section{Conflict of interests}

Author declares no conflict of interest

\section{REFERENCES}

Adamek, I., Bałachowicz, J., \& Impuls, O. W. (Eds.). (2014). Kompetencje kreatywne nauczyciela wczesnej edukacji dziecka. [Creative competence of an early childhood education teacher] Oficyna Wydawnicza" Impuls". Retrieved from: http://cejsh.icm.edu.pl/cejsh/element/bwmeta1. element.desklight-4c717862-1dbc-4eaa-9bc0e32a4dbe811d

Anderson, L. W., Krathwohl, D. R., \& Airasian, P. W. (2000). A Taxonomy for Learning, Teaching, and Assessing: A Revision of Bloom's Taxonomy of Educational Objectives. Retrieved from: https://www.semanticscholar.org/paper/ATaxonomy-for-Learning $\% 2 \mathrm{C}$-Teaching $\% 2 \mathrm{C}$ and-Assessing $\% 3 \mathrm{~A}-\mathrm{A}$-Anderson-Krathwohl/2 3eb5e20e7985fca5625548d2ee6d781a2861d41

Buzan, T. (2014). Mapy twoich myśli. [Maps of your thoughts], Wydawnictwo: Aha. Łódź. Retrieved from: https://www.gwp.pl/mapy-twoich-mysli. pdf

De Bono, E. (2015). Myślenie lateralne. [Lateral thinking]. Wydawnictwo: StudioEMKA Warszawa. Retrieved from: https://www. empik.com/myslenie-lateralne-de-bonoedward,p1109017106,ksiazka-p

Dobrołowicz, W. (1995). Psychodydaktyka kreatywności. [Psycho-didactics of creativity]. Wyższa Szkoła Pedagogiki Specjalnej im. Marii Grzegorzewskiej.

Edwards, C., Gandini, L., \& Forman, G. (Eds.). (2011). The Hundred Languages of Children: The Reggio Emilia Experience in Transformation: The Reggio Emilia Experience in Transformation. ABC-CLIO. Retrieved from: https://books. google.rs/books?hl=en \&lr=\&id=LEgm-z5f os4C\&oi $=$ fnd \&pg $=$ PP $1 \& d q=$ Edwards $,+C,+$ Gandini,+L.+(2011).+The+hundred+langua ges+of+children:+The+Reggio+Emilia+ex perience + in + transformation. + Santa + Barbar $\mathrm{a},+$ California\&ots $=\mathrm{mp}$ AjI9tcX\&sig=hbA_ S0g0wrpWPnyMRbMA_r_UTOY\&redir ${ }^{-}$ esc $=\mathrm{y} \# \mathrm{v}=$ onepage $\& \mathrm{q}=\overline{\mathrm{E}} \mathrm{dw}$ ards $\% 2 \mathrm{C} \% 2 \overline{0}$ C\%2C\%20Gandini\%2C\%20L.\%20(2011).\%20 The $\% 20$ hundred $\% 20$ languages $\% 20$ of $\% 20$ children $\% 3$ A $\% 20$ The $\% 20$ Reggio $\% 20$ Emilia $\% 20$ experience $\% 20$ in $\% 20$ transformation. $\% 20$ Santa $\% 20$ Barbara $\% 2 \mathrm{C} \% 20$ California\& $\mathrm{f}=$ false

Giza, T. (2006). Socjopedagogiczne uwarunkowania procesAtw identyfikowania oraz rozwoju zdolności uczniów w szkole. [Socio-pedagogical conditioning of identification processes and development of students' abilities at school], Wydawnictwo Akademii Świętokrzyskiej. Kielce. Retrieved from: https://tezeusz.pl/ socjopedagogiczne-uwarunkowania-procesowidentyfikowania-oraz-rozwoju-zdolnosciuczniow-w-szkole-1545600

Klus-Stańska, D. (2010). Dydaktyka wobec chaosu pojęć $i$ zdarzen. [Teaching in the face of chaos of concepts and events], Wydawnictwo Akademickie" Żak". Retrieved from: http:// terazniejszosc.dsw.edu.pl/fileadmin/user_ upload/wydawnictwo/TCE/2011_53_7.pdf

Kožuh, A. (2016). Kreatywność jako niezbędny element kompetencji nauczyciela w edukacji alternatywnej. [Creativity as an essential element of teacher's competence in alternative education], Państwo i Społeczeństwo, 16(2), 3954. Wydawnictwo: Oficyna Wydawnicza KA AFM. Retrieved from: https://www.ceeol.com/ search/article-detail?id $=586144$

Kožuh, A. (2017). Active pupils at school. Založništvo in izdelava -Koper: University of Primorska Press, Retrieved from: https://plus.si.cobiss.net/ opac $7 / \mathrm{bib} /$ search? $\mathrm{q}=$ slovenija\&db=cobib\&mat $=$ allmaterials $\&$ auf $=$ coti $\% \mathrm{C} 4 \% 8 \mathrm{D} \% 2 \mathrm{C}+$ mara $\& \mathrm{t}$ gf $=$ odrasli\&tyf $=0$ knj\&ucf $=37.091 .3 \&$ laf $=$ eng

Kwaśnica, R. (2007). Dwie racjonalności: od filozofii sensu ku pedagogice ogólnej. [Two rationalities. From the philosophy of sense to general pedagogy], Wydawnictwo Naukowe Dolnośląskiej Szkoły Wyższej Edukacji TWP we Wrocławiu. Retrieved from: https://opub. dsw.edu.pl/bitstream/11479/138/1/Dwie racjonalnosci.pdf

Limont, W. (2005). Wykorzystanie myślenia metaforycznego $w$ edukacji ku twórczości. [Making use of metaphorical thinking in education encouraging creativity]: in A. Tokarz (Ed.). W poszukiwaniu zastosowań psychologii twórczości (ss.93 - 123). [In quest of applications of the psychology of creativity], 
Wydawnictwo Uniwersytetu Jagiellońskiego, Kraków. Retrieved from: http://www.zea.umk. pl/wieslawa-limont/

Łukasiewicz, M. (2007). Mistrzostwo. Jak pobijać własne rekordy $w$ szybkim i skutecznym uczeniu się. [Expert skill. How to break your own records in fast and effective learning], Wydawnictwo: Rebis. Poznań.

Melosik, Z., \& Szkudlarek, T. (2009). Kultura, tożsamość $i$ edukacja: migotanie znaczeń. [Culture, identity, and education. Fluttering meanings]. Oficyna Wydawnicza Impuls. Retrieved from: http://swarzedz.pbp.poznan.pl/ files/kultura.pdf

Moroz, H. (1996). Rozwijanie twórczości w procesie kształcenia nauczycieli. [Developing creativity in the teacher education process] In: S. Juszczyk (Ed.). Twórczy rozwój nauczyciela. [Creative development of teachers]. Wydawnictwo: Impuls. Kraków.

Nęcka, E. (1998). Trening twórczości, Podręcznik dla psychologów, pedagogówinauczycieli. [Training creativity. A hand book for psychologists, educators and teachers], Oficyna Wydawnicza: Impuls, Kraków. Retrieved from: https:// integro.ciniba.edu.pl/integro/191800870905/ necka-edward/trening-tworczosci, https://fbc. pionier.net.pl/details/nnzggf6

Nęcka, E. (2001). Psychologia twórczości. [Psychology of creativity], Gdańskie Wydawnictwo Psychologiczne. Gdańsk. Retrieved from: https://www.scribd.com/document/371869239/ E-Necka-Psychologia-Tworczosci

Nęcka, E., Orzechowski J., Słabosz A., Szymura B. (2005). [Training creativity], Gdanskie Wydawnictwo Psychologiczne, Gdańsk. Retrieved from: https://usosweb.aps.edu. $\mathrm{pl} /$ kontroler.php? action $=$ katalog $2 \% 2 \mathrm{Fprz}$ edmioty\%2Fpokaz̄Przedmiot\&kod=10-1STKR\&lang=en

Olearczyk, T. (2010). Pedagogia ciszy. [Pedagogy of silence]. Wydawnicwto: WAM, Kraków.

Pachociński, R. (1998). Podstawy kształcenia wyższych umiejętności poznawczych $w$ nowoczesnej szkole. [Basics of teaching high er cognitive skills in a modern school], Wydawnictwo Instytutu Badań Edukacyjnych, Warszawa.

Popek, S. (2001). Człowiekjakojednostka twórcza. [Man as a creative individual], Wydaw. Uniwersytetu Marii Curie-Skłodowskiej, Lublin.

Pólturzycki, J. (2013). Dydaktyka dla nauczycieli. [Didactics for teachers], Wydawnictwo: Adam Marszałek, Toruń. Retrieved from: https:// tezeusz.pl/dydaktyka-dla-nauczycieli-jozefpolturzycki

Renzulli, J. S. (1976). The enrichment triad model: a guide for developing defensible programs for the gifted and talented. Gifted Child Quarterly, 20(3), 303-306. https://doi. org/10.1177/001698627602000327

Renzulli, J. S., \& Reis, S. M. (2009). Light up your child's mind: Finding a unique pathway to happiness and success. Little, Brown. Retrieved from: https://s3.amazonaws.com/academia.edu. documents/34624962/GTI 2010.pdf?responsecontent-disposition = inline $\% 3 \mathrm{~B} \% 20$ filename $\% 3 \mathrm{DA}$ new look at creative giftedness.pdf $\& \overline{\mathrm{X}}-\mathrm{Am} \overline{\mathrm{Z}}-\mathrm{Alg}$ orithm=AWS4HMAC-SHA256\&X-Amz-Credential $=A K$ IAIWOWYYGZ2Y 53UL3 A\%2F20200302
$\% 2$ Fus-east- $1 \% 2$ Fs $3 \% 2$ Faws 4 request\&XA m z - D a t e $=20200302$ T $08 \overline{2} 940 \mathrm{Z} \& \mathrm{X}$ A m z - Ex p i r e s = $3600 \& X-A m z-$ SignedHeaders $=$ host $\& X-A m z-$ Signature $=5 \mathrm{deb}$ ef00084704031503d042e0fc3dceca209aeeda07 ee $505 \mathrm{c} 84720615 \mathrm{~b} 9 \mathrm{c} 89 \mathrm{a} \#$ page $=128$

Smak, E. (2014). Innowatyka w edukacji. [Innovativeness in education], Wydawnictwo: Nowik, Opole. Retrieved from: https://www. nowik.com.pl/product/innowatyka-w-edukacji

Szmidt, K. (2013). Trening kreatywności. [Training creativity], Wydawnictwo: Helion, Gliwice. Retrieved from: https://pdf.helion.pl/trekr2/ trekr2.pdf

Śliwerski, B. (2007). Wychowanie. Pojęcia-znaczenia - dylematy. [Education. Concepts - meanings dilemmas], In: M. Dudzikowa, M. Czerepaniak - Walczak (Eds.). Wychowanie. Pojęcia. Konteksty. (Education. Concepts. Contexts.] Wydawnictwo: GWP, Gdańsk. Retrieved from: https://www.gwp.pl/wychowanie-tom1 -pojecia-procesy-konteksty-istota-i-senswychowania-wokol-kontekstow-i-znaczen.pdf

Teśluk, M. (1999). Nauczyciel - kreator w reformowanej szkole. [Teacher - a wizard in the reformed school], In: J. Łaszczyk (Ed). Pedagogika czasu przemian. [Pedagogy of the time of change] Wydawnicwto: ZM WSPS, Warszawa. Retrieved from: https://integro.ciniba.edu.pl/ integro/191800824077/ksiazka/pedagogikaczasu-przemian

Tokarz, A. (2005). Dynamika procesu twórczego. [The dynamics of the creative process], Kraków: Wydawnictwo Uniwersytetu Jagiellońskiego. Retrieved from: https://www.medicon.pl/ dynamika-procesu-tworczego/2980

Urbańska, E. (2014). Rola twórczości zawodowej nauczycieli w procesie rozwoju współczesnej szkoły. [The role of teachers' professional creativity in the development process of the contemporary school. Educational Quarterly], Kwartalnik Edukacyjny 2014 nr 1 pp 5561. Warszawa. Retrieved from: http://www. bpsiedlce.pl/1/strona/81_zestawieniabibliograficzne/287_psychologia/182 kreatywnosc/

Żechowska, B. (1996). O twórczym rozwoju nauczyciela refleksji kilka. [A few reflections on the creative development of teachers] In: S. Juszczyk (Ed). Twórczy rozwój nauczyciela. [Creative development of teachers], Wydawnictwo: Impuls, Kraków. Retrieved from: https:// allegro.pl/oferta/tworczy-rozwoj-nauczycielastanislaw-juszczyk-7931724185

Włochy: wyjątkowa praca domowa na lato dla uczniów liceum - strona internetowa [Italy: exceptional summer homework for high school students], Retrieved June, 11.2015. http://wiadomosci. onet.pl/swiat/wlochy-wyjatkowa-pracadomowa-na-lato-dla-uczniow-liceum/5ddhtk

Wrocław. Wyborcza: 10 - letni Natan napisał opowiadanie - strona internetowa [Ten-yearold Natan wrote a short-story], Retrieved July, 24.2018. http://wroclaw.wyborcza.pl/ wroclaw/7,35771,23416369,10-letni-natannapisal-opowiadanie-nauczycielka-kazalapoprawic.html 